\title{
Influence of a permanent liner on the skin friction of large-diameter bored piles in Hong Kong granitic saprolites
}

\author{
S.-C.R. Lo and K.S. Li
}

\begin{abstract}
The skin friction of large-diameter bored piles in Hong Kong granitic saprolite manifested high variability. The influence of one construction detail, a full-length permanent liner, is studied by examining full-scale load test results and by numerical simulation of this construction detail. It is concluded that the use of a full-length liner will give very low skin friction because the local method of constructing a large-diameter bored pile with a full-length permanent liner leads to a significant reduction in radial stress acting on the pile-soil interface.
\end{abstract}

Key words: construction, pile, stress, skin friction, numerical simulation.

Résumé : Le frottement sur la superficie cylindrique de pieux de grands diamètres forés dans la saprolite granitique de Hong Kong a montré une forte variabilité. On a étudié l'influence d'un détail de construction, soit une membrane pleine longueur, en examinant les résultats d'essais de chargement à pleine échelle et par simulation numérique de ce détail de construction. On a conclu que l'utilisation de membrane à pleine longueur va donner un très faible frottement superficiel sur le pieu. Ceci est dû à la méthode locale de construction des pieux forés à grands diamètres avec une membrane permanente à pleine longueur qui va conduire à une réduction significative de la contrainte radiale agissant sur l'interface sol-pieu.

Mots clés : construction, pieu, contrainte, frottement superficiel, simulation numérique.

[Traduit par la Rédaction]

\section{Introduction}

Hong Kong has a population in excess of six million but a total land area, including land reclaimed from the sea, of just in excess of $1000 \mathrm{~km}^{2}$. Due to intense urban development, design decisions are often driven by land constraints. Furthermore, all major buildings and infrastructures have to be designed to resist the most severe tropical cyclone. Therefore, high column loads and large, machine-excavated replacement piles, such as circular bored piles or barrettes (rectangular replacement piles excavated under a bentonite slurry), are commonplace in Hong Kong. This paper, however, only addresses machine-excavated circular bored piles.

If bedrock is encountered at a depth not exceeding $40 \mathrm{~m}$, conventional design procedure is to found the pile on bedrock and relies purely on end bearing capacity. Bedrock in urbanized areas of Hong Kong is mostly granitic or volcanic, and high end bearing capacity can be achieved. Due to the spheroidal weathering process (Ruxton and Berry 1957),

Received 24 June 2002. Accepted 26 February 2003.

Published on the NRC Research Press Web site at

http://cgj.nrc.ca on 5 August 2003.

S.-C.R. Lo. ${ }^{1}$ School of Civil Engineering, University of New South Wales, ADFA, Canberra, ACT 2600, Australia.

K.S. Li. Victor Li \& Associates Ltd., Chevalier Commercial Building, Wang Hoi Road, Kowloon Bay, Hong Kong, and University of Hong Kong, Department of Civil Engineering, Pokfulum Road, Hong Kong.

${ }^{1}$ Corresponding author (e-mail: srl@octarine.cc.adfa.edu.au). however, the bedrock surface may not be clearly defined. Hence, local practice relies on the prescriptive procedures of Practice Note PNAP-141 (Hong Kong Government 1995) issued by the Building Department, Hong Kong Government, in determining the founding level of a bored pile end bearing on rock. PNAP-141 gives an allowable bearing pressure of $5000 \mathrm{kPa}$ if the founding material has a total (rock) core recovery of no less than $85 \%$, and the recovered cores have unconfined compressive strength (UCS) $\geq 25 \mathrm{MPa}$. For a more superior rock condition (as defined in PNAP-141), an allowable bearing pressure of $7500 \mathrm{kPa}$ may be used. When bedrock satisfying the acceptance criteria stipulated in PNAP-141 for the $5000 \mathrm{kPa}$ allowable bearing pressure is excessively deep, the designer may found the pile in the overlying completely to highly decomposed granitic or volcanic rocks, which are soil-like materials referred to as saprolites in this paper. For such a design scenario, the axial capacity of the bored pile will be derived mainly from skin friction in the saprolite stratum.

Bored piles supported by skin friction in granitic saprolite have been successfully used in Hong Kong since the early 1980s, notably in the projects of Telford Gardens (Holt et al. 1982) and the Island Eastern Corridor (Fraser 1985; Fraser and Kwok 1986). A number of full-scale pile tests were conducted in an attempt to justify the choice of design skin friction values. It is pertinent to note that most of the load test data are for granitic saprolite. The measured skin friction, however, manifested considerable variability and was, on the average, significantly lower than values reported in the literature (Meyerhof 1976; Touma and Reese 1974; Reese and 
Wright 1977; Reese and O'Neill 1988; Chang and Broms 1991; Chang and Wong 1995; Tan et al. 1998). This "relatively lower" skin friction of bored piles in saprolite, and its high variability, has been examined in a number of papers. Malone et al. (1992) stated that "there appears to be no order ..." in the variation of skin friction. $\mathrm{Ng}$ et al. (2000), based on selected test results, suggested that skin friction of "well constructed" bored piles can be estimated with simple design equations. Lo and $\mathrm{Li}$ (2000) suggested that skin friction values in saprolites are sensitive to "details" of the pile installation, which often did not form part of the method statement or construction specification. The broad objective of this paper is to study the possible adverse effects on skin friction due to one particular construction detail, the use of a full-length permanent liner. This construction detail can have a very significant adverse effect on skin friction. The performance of four full-scale test piles constructed with liners in granitic saprolites was examined. The installation of a permanent liner in bored pile construction and its effects on skin friction were also simulated numerically.

\section{Ground conditions}

The subsurface conditions overlying granitic bedrock can be simplified as shown in Fig. 1a. Bedrock is overlain by highly decomposed granite, which transitions into completely decomposed granite. Both materials are soil-like materials that retain some of the fabric of the parent rock, with the possible exception of the top few metres of the completely decomposed zone (Lumb 1983; Au 1998). These structured soils are collectively referred to as saprolites (or, more precisely, granitic saprolites), and this is the term used in this paper. Due to the spheroidal weathering process (Ruxton and Berry 1957), core stones may be left in the saprolite stratum. The engineering characteristics of granitic saprolites are well documented in the milestone publications of Lumb (1962a, 1983), and the findings of other researchers are summarized in Au (1998). The engineering properties of granitic saprolites are briefly described here. Granitic saprolite is a silty clayey sand with a standard penetration test (SPT) blow count value in excess of 40 for completely decomposed granite and increasing to 200 for highly decomposed granite. The mass permeability is of the order of $10^{-5}$ to $10^{-7} \mathrm{~m} / \mathrm{s}$ (Lumb 1962a, 1962b, 1975; GEO 1993). A secondary porosity system is likely to be present in saprolites (Au 1990, 1998), and this further increases the drainage rate of small zones. Therefore, pile design is based on drained behaviour. As reported in Au (1998), granitic saprolite has a failure surface consisting of two zones as illustrated in Fig. $1 b$ : a curved zone with the shape of a "bump" at a lower effective confining stress, and a linear zone at a higher effective confining stress. Granitic saprolite may have a small effective cohesion, but it is still a matter of debate whether the values reported in the literature are partly or largely due to linearizing curved failure surfaces. It is commonly assumed that granitic saprolite is dilatant at failure, but $\mathrm{Au}$ (1998) suggested that this is conditional upon the failure stress state located on the curved part of the failure surface. These behaviour patterns are consistent with those of structured soils (Leroueil and Vaughan 1990). The top zone of the completely decomposed zone may become a structureless resid- ual soil with a higher fines content (Irfan 1996). This structureless soil, usually only a few metres thick, is sometimes referred to as residual soil or "red earth" (Lumb $1962 a$, 1965) and has lower SPT values. The terminology used by local engineers (and to some extent researchers) to describe the soil derived from in situ decomposition of granite can be confusing. It is noted that the term decomposed granite (DG) is often used interchangeably with saprolite in pile design, although the latter, strictly speaking, includes the structureless residual soil. Occasionally, the term decomposed granite is also used quite misleadingly to denote all geomaterials, from rock-like materials to structureless soil, derived from the in situ decomposition of granite. The residual soil is usually covered with weaker superficial deposits. The superficial deposits may be colluvium and topsoil in the hilly areas or old alluvium, marine deposits, and fill in the reclaimed areas. It is not uncommon to encounter superficial deposits with a total thickness in excess of $20 \mathrm{~m}$. The water table is generally encountered prior to reaching founding level, and it is generally not feasible to dewater the pile excavation unless the complete pile periphery is grouted. Hence most machine-excavated bored piles were constructed under water. For a variety of practical reasons, including the possibility of negative friction drag-down from the superficial deposits due to subsequent adjoining developments, the skin friction support from the superficial deposits is not included in calculating friction capacity of a large-diameter bored pile.

\section{Pile construction}

Large-diameter bored piles in Hong Kong are mostly excavated either by hammer grabbing (HG) or reverse circulation drilling (RCD). These two methods of installation enable excavation of $3 \mathrm{~m}$ diameter piles to depths exceeding $70 \mathrm{~m}$. To ensure the required pile penetration into the saprolite stratum, it is common practice to sink a borehole (with SPT taken) in the saprolite stratum at a pile or column position.

\subsection{Pile excavation techniques}

The HG method is sometimes referred to as the casing method. This term will not be used in this paper, however, as both HG and RCD involve the sinking of an excavation casing. In the HG method, a heavy-duty excavation casing is sunk by an oscillator, rotator, or vibrating hammer, and the soil inside the casing is excavated by a heavy grab (Fig. $2 a$ ). Because of the size of the bored pile and the strength of the undisturbed saprolites, excavation and sinking of the casing must proceed in parallel. This pile excavation technique can be used for superficial deposits, old alluvium, residual soil, or saprolite. In principle, the casing toe should be kept ahead of the excavation. For the RCD method (Fig. $2 b$ ), a casing is sunk using an oscillator or techniques similar to $\mathrm{HG}$ until saprolite is encountered. Pile excavation is then conducted using a special drill rig and the excavated materials flushed back to the surface by the reverse circulation technique. The drill shaft in the saprolite stratum is uncased. The drilling fluid, in addition to being a carrier for flushing the excavated material, provides a controlled positive differential pressure to support the uncased pile excavation. The drill fluid can be 
Fig. 1. (a) Typical subsurface conditions. (b) Failure surface of granitic saprolite (schematic).
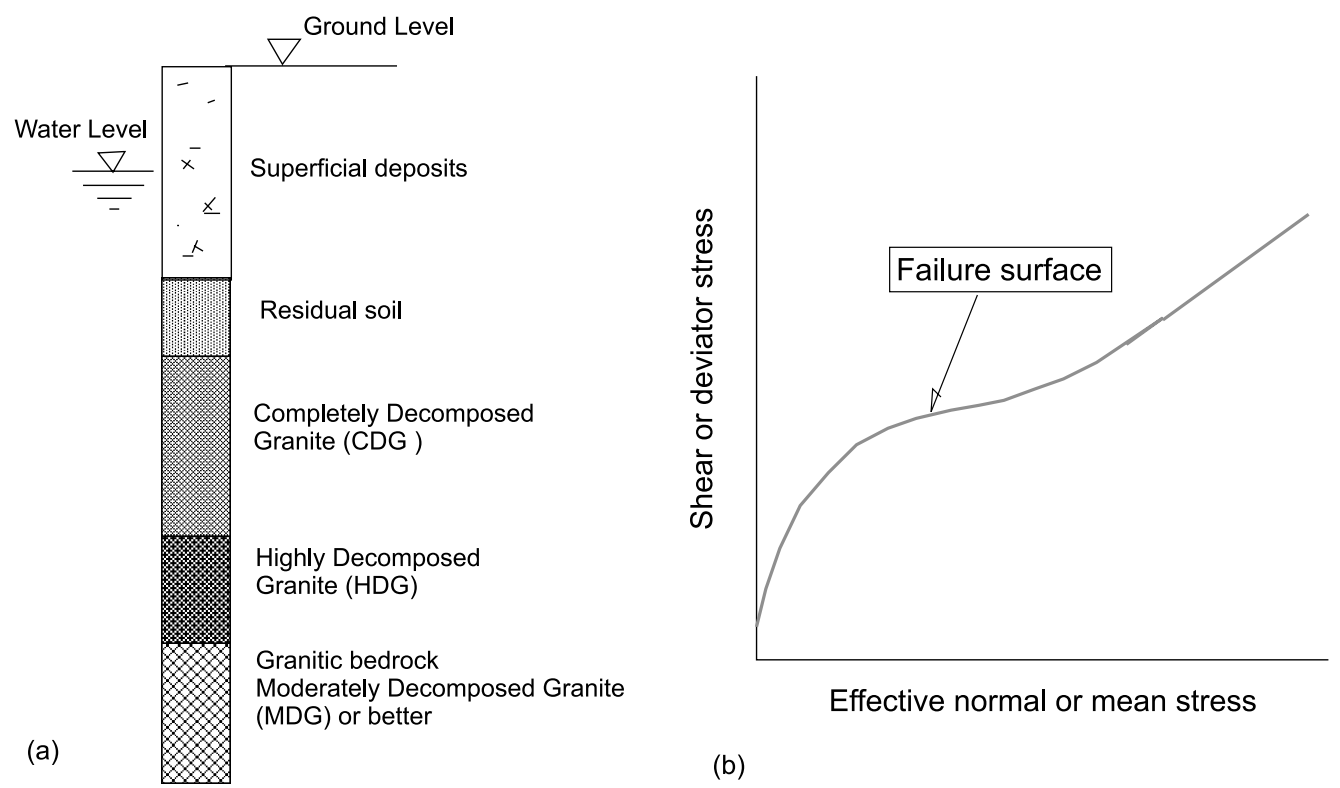

Fig. 2. Construction methods: $(a)$ hammer grabbing; $(b)$ reverse circulation drilling. GL, ground level; WT, water table.
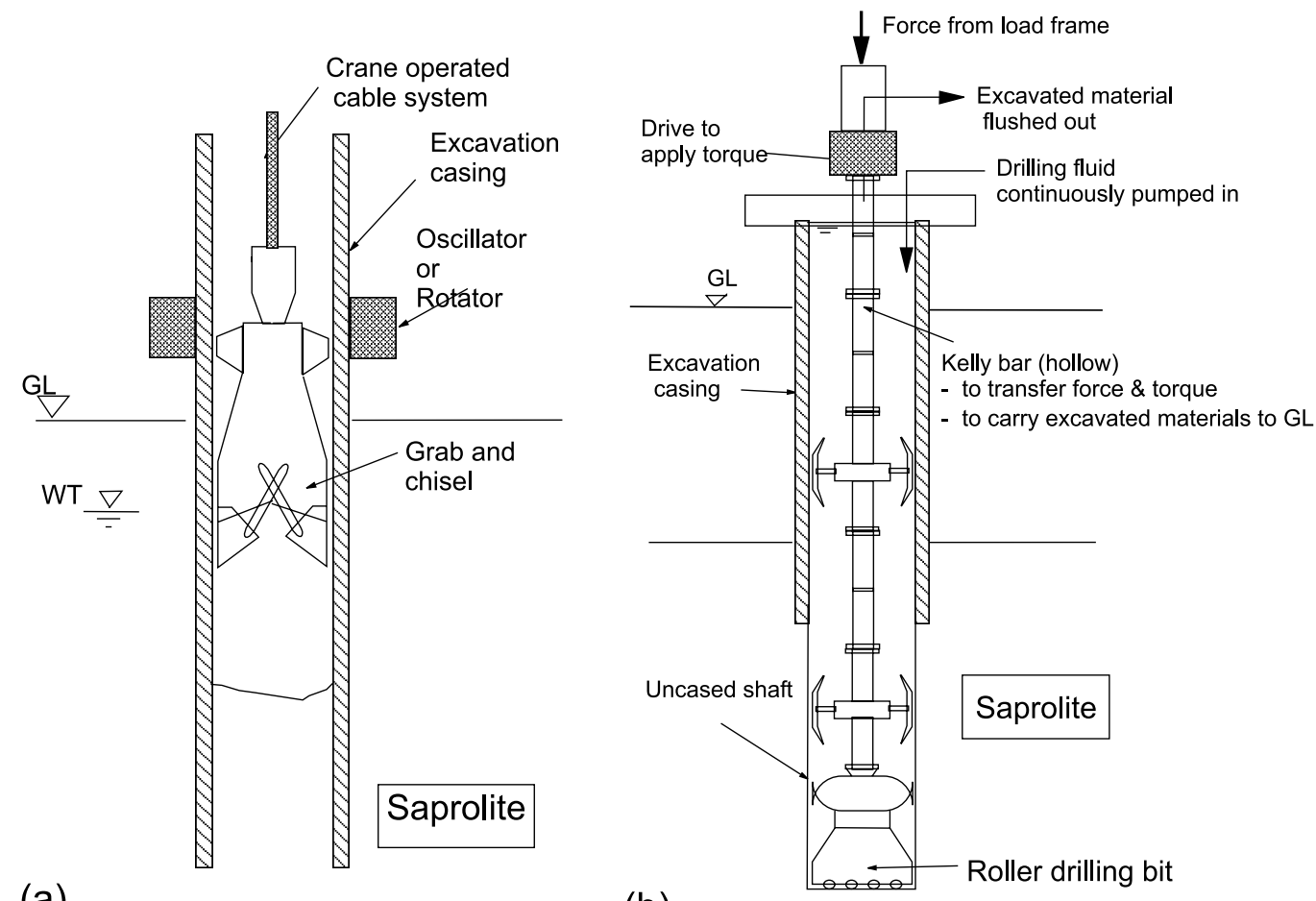

(a)

(b)

water (Au and Lo 1993) or bentonite slurry. The pile shaft in the saprolite stratum may be partly excavated by $\mathrm{HG}$ but completed with RCD. The excavation casing will be recovered either during or after concreting, and this will leave a very rough pile surface, as attested by the many bored piles exposed in deep basement or cut-and-cover tunnel construction in Hong Kong.

\subsection{Permanent liner}

Irrespective of whether the HG or RCD method is used, a corrugated permanent (sacrificial) thin steel liner for the up-

per (weaker) strata may be installed as illustrated in Fig. $3 a$ for constructability reasons such as enabling the use of oversized excavation casing to facilitate the removal of boulders. The liner also provides a gap for the installation of a slip layer (such as bentonite) for reducing potential negative friction drag-down from the fill and marine deposit strata caused by adjoining developments. This liner may be extended along the full length of the pile (and sitting on the base of the pile excavation) as illustrated in Fig. $3 b$ simply for the sake of easier installation and (or) to avoid mixing of concrete with groundwater in the overbreaks of the saprolite 
Fig. 3. Permanent liner in bored pile construction: $(a)$ liner over superficial deposits; $(b)$ full-length liner.

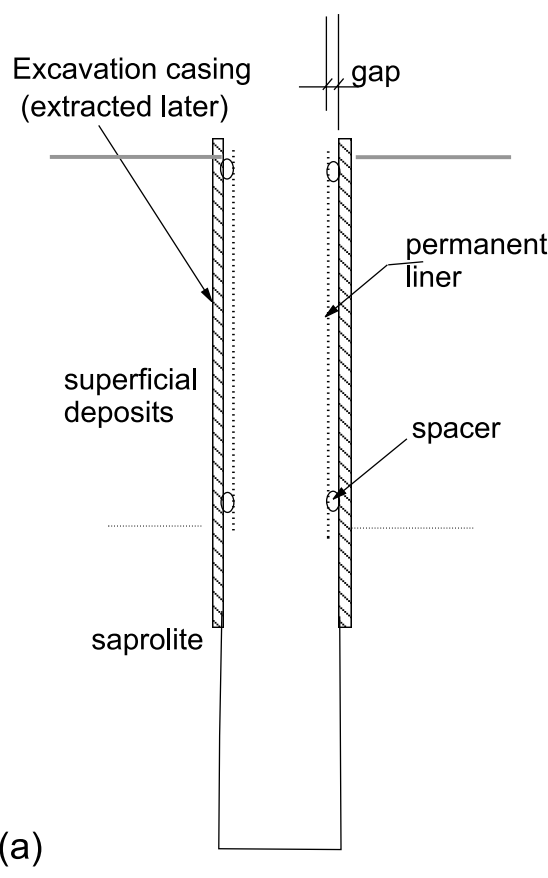

stratum. For a pile end bearing on bedrock, the provision of a full-length permanent liner may be considered by some engineers as a good construction practice, since it eliminates the possibility of soil slumping into the pile base.

For piles founded in saprolites, a full-length permanent liner always creates a temporary annular void. This gap (void) is usually 100-200 mm. The tremie concrete may not flow up into this annulus space. It is considered that the saprolite in the vicinity of a pile will have its true cohesion destroyed by pile construction and will collapse into the annular void.

\section{Case histories}

\subsection{Data base}

The authors examined 22 large-diameter bored pile load test results from 10 sites (Lo and Li 1999, 2000). All load tests were conducted with a maintained load. The test results were analysed with respect to $\tau_{\mathrm{f}}, \tau_{\mathrm{f}} / N$, and $\beta$, where $\tau_{\mathrm{f}}$ is the measured skin friction, $N$ is the SPT value, and $\beta$ is the design parameter of the beta design method expressed as follows:

$$
\tau_{\mathrm{f}}=\beta \cdot \sigma_{\mathrm{vo}}^{\prime}
$$

where $\sigma_{\mathrm{vo}}^{\prime}$ is the effective vertical stress prior to pile installation. In the interpretation of load test results, $\tau_{\mathrm{f}}, N$, and $\sigma_{\mathrm{vo}}^{\prime}$ are average values over an instrumented pile segment. The key data for these test piles are listed in Tables 1 and 2. Test piles listed in Table 1 were instrumented with strain gauges for measurement of skin friction; the piles listed in Table 2 were not instrumented with strain gauges, but the average skin friction can be estimated from the loadsettlement curves based on Poulos and Davies (1980). For the sake of completeness, these load test results are briefly discussed in Appendix A. The measured skin friction in the

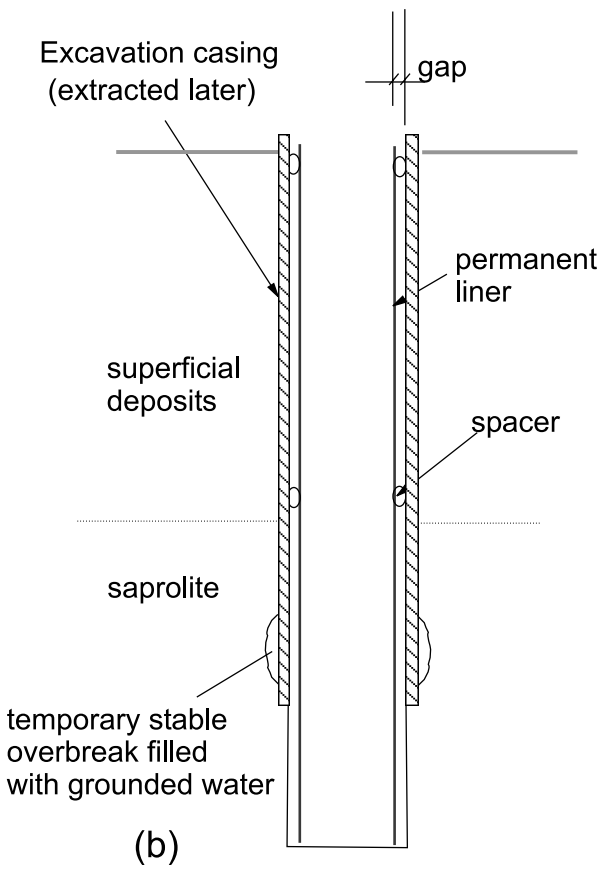

saprolite stratum (i.e., data from Table 1) can be characterized by the statistical attributes as summarized in Table $3 \mathrm{~A}$.

The statistical attributes of the measured skin friction, in terms of both variability and mean value, can be notably improved if bored piles constructed with a full-length permanent liner were excluded from the data base. These improved statistical attributes are listed in Table 3B. As discussed in Appendix A, however, Table 3B still gives skin friction values that, on average, are significantly less than those given by common design methods (Meyerhof 1976; Reese and Wright 1977; Touma and Reese 1974; Reese and O'Neill 1988).

\subsection{Performance of piles constructed with full-length permanent liners}

The data base contained four piles (three sites) constructed with permanent full-length liners. All four piles manifested extremely low skin friction values and may be viewed as outliers of the data base. Therefore, these four load test results are examined in detail in the following sections.

\subsubsection{Western end of the IEC stage 1}

At the western end of the IEC stage 1 project, near Causeway Bay, two instrumented piles (piles 13/4 and 10/5) were constructed with a full-length permanent liner and load tested in the early 1980s. Pile 13/4 was constructed by HG within a $1.5 \mathrm{~m}$ diameter excavation casing. The diameter of the liner was $1.2 \mathrm{~m}$. Pile 10/5 was constructed by RCD, however, within a $1.7 \mathrm{~m}$ diameter casing and using a $1.5 \mathrm{~m}$ diameter liner. The ground conditions penetrated by these two piles are presented in Fig. 4. As reported in Fraser $(1985), \tau_{f}$ values of these two piles were extremely low and only the skin friction over the complete length of pile embedded in the saprolite stratum could be inferred. For pile $13 / 4$, the maximum test load was $10 \mathrm{MN}$ and the skin fric- 


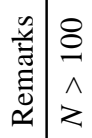

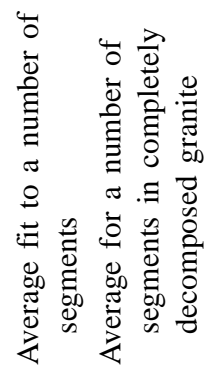

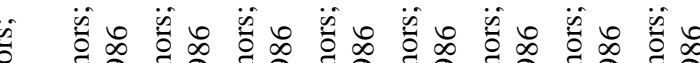

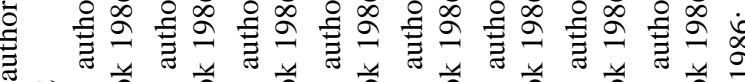

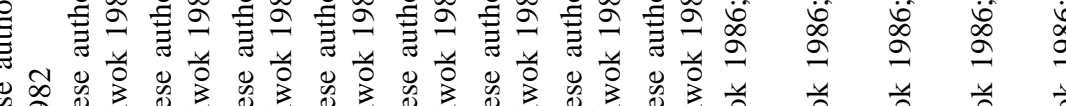

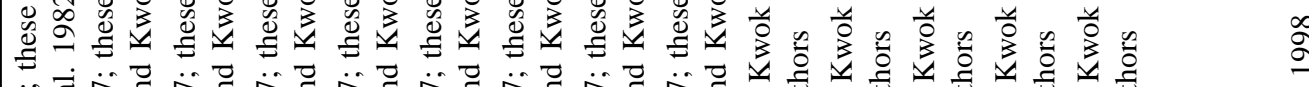

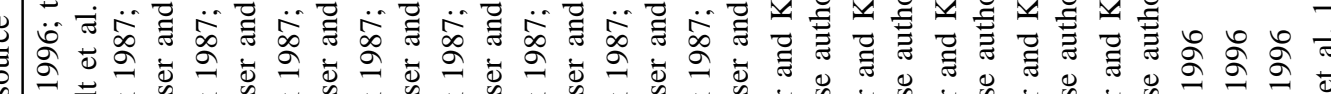

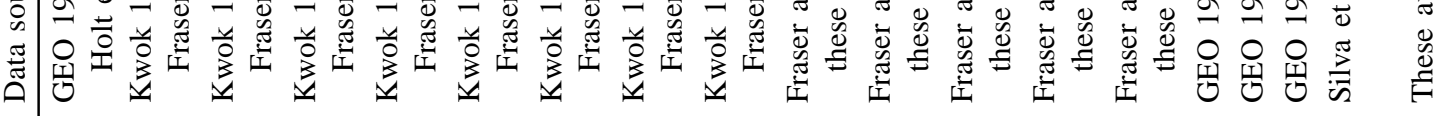

$\infty$

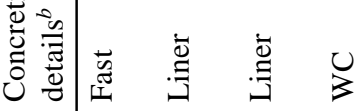



$\vdots$

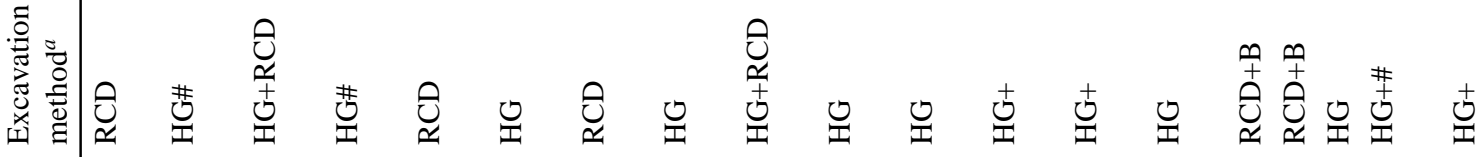

ص

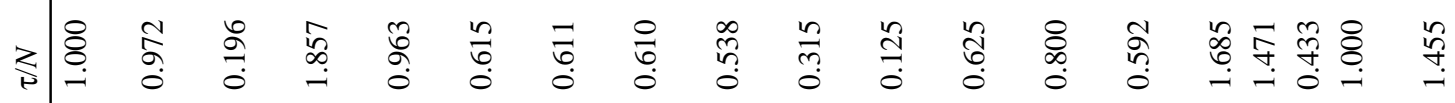

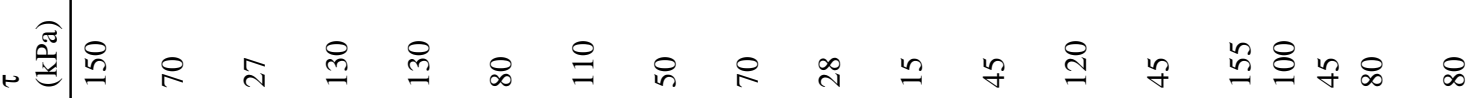

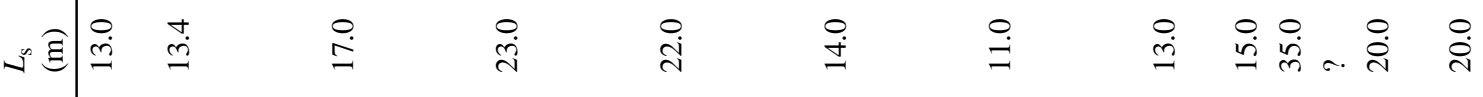

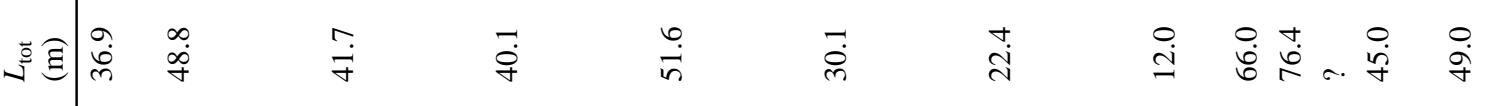

๑ ह

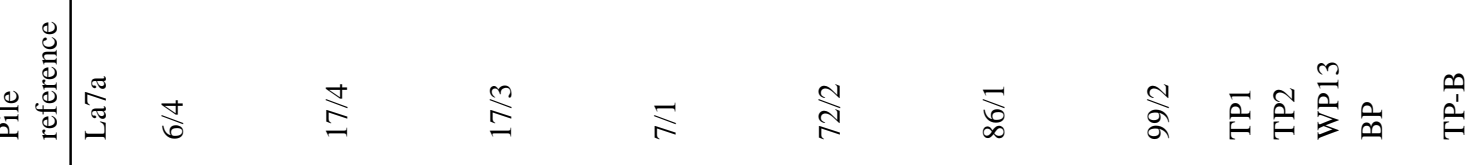

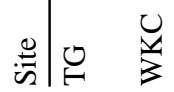

$\underset{⿴ 囗 十)}{\cup}$

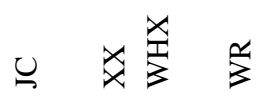



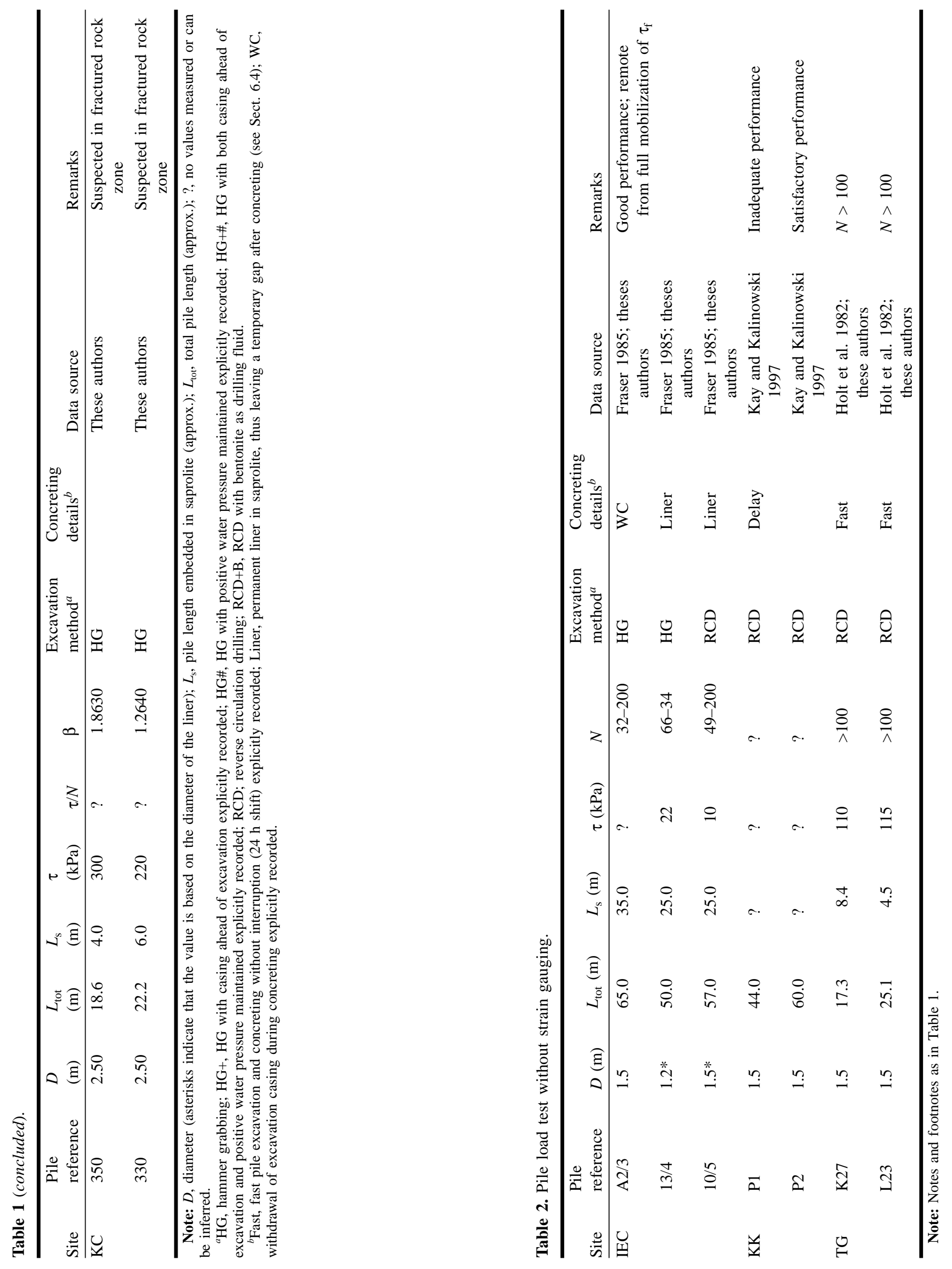
Table 3. Statistical attributes of measured skin friction in saprolite.

\begin{tabular}{|c|c|c|c|}
\hline Parameter & Mean & $\begin{array}{l}\text { Coefficient of } \\
\text { variation }(\%)\end{array}$ & Range \\
\hline$\tau_{\mathrm{f}}(\mathrm{kPa})$ & 97 & 70 & $15-155$ \\
\hline$\tau_{\mathrm{f}} / N$ & 0.83 & 59 & $0.13-1.86$ \\
\hline$\beta$ & 0.25 & 61 & $0.06-0.68$ \\
\hline
\end{tabular}

(B) Data for all piles except those installed with a fulllength permanent liner.

\begin{tabular}{llll}
\hline Parameter & Mean & $\begin{array}{l}\text { Coefficient of } \\
\text { variation }(\%)\end{array}$ & Range \\
\hline$\tau_{\mathrm{f}}(\mathrm{kPa})$ & 112 & 60 & $45-220$ \\
$\tau_{\mathrm{f}} / \mathrm{N}$ & 0.95 & 48 & $0.43-1.86$ \\
$\beta$ & 0.287 & 53 & $0.12-0.68$ \\
\hline
\end{tabular}

Note: Range is reported to two decimal places, and the two piles from site KC (with very high $\tau_{\mathrm{f}}$ ) are excluded.

tion force developed over $25 \mathrm{~m}$ penetration into saprolite was about $2000 \mathrm{kN}$, giving an average $\tau_{\mathrm{f}}$ of only $\sim 22 \mathrm{kPa}$. For pile $10 / 5$, at a maximum test load of $9.5 \mathrm{MN}$, the average $\tau_{\mathrm{f}}$ over $25 \mathrm{~m}$ in saprolite was less than $10 \mathrm{kPa}$.

\subsubsection{Eastern end of the IEC stage 1}

At the eastern end of the site, a $1.5 \mathrm{~m}$ diameter bored pile constructed over water, referred to as pile $72 / 2$, was constructed and tested. Since the location of this test pile is more than $2 \mathrm{~km}$ away from the western end of the project, it is considered as a "separate site" for the purpose of this study. The pile had an embedded length of $30 \mathrm{~m}$ and penetrated ground conditions as illustrated in Fig. 5. It was excavated with the HG method using an oversized excavation casing for the first $35 \mathrm{~m}$, but RCD was used for the last $5 \mathrm{~m}$. A full-length permanent liner was installed prior to concreting. The maximum test load was $10.5 \mathrm{MN}$. The strain gauge readings gave the following $\tau_{\mathrm{f}}$ values in the saprolite stratum: $(i)$ for penetration $13.0-18.5 \mathrm{~m}, \tau_{\mathrm{f}}=28 \mathrm{kPa}, \tau_{\mathrm{f}} / N=$ 0.315 , and $\beta=0.178$; (ii) for penetration $18.5-23.5 \mathrm{~m}, \tau_{\mathrm{f}}=$ $15 \mathrm{kPa}, \tau_{\mathrm{f}} / N=0.125$, and $\beta=0.071$. These skin friction values were very low compared with the statistical attributes of bored piles in Hong Kong granitic saprolites (Table 3), and such low values were considered as "unexpected" (Fraser and Kwok 1986).

\subsubsection{WKC site}

The influence of a full-length permanent liner can be studied in detail with reference to two test piles, $6 / 4$ and 17/4, at the WKC site (Kwok 1987). The second pile was not constructed with a permanent liner but served as a controlled test pile. The ground conditions penetrated by these two piles are presented in Fig. 6. Test pile $6 / 4$ was $48.8 \mathrm{~m}$ in length and penetrated $13.5 \mathrm{~m}$ into saprolite. It was excavated with $\mathrm{HG}$ to $\sim 5 \mathrm{~m}$ from the pile toe level. The last $5 \mathrm{~m}$ was excavated with RCD. At the time of the construction, the potential adverse effects of the annulus void were recognised. In an attempt to improve the properties of the annulus of loose materials formed by the surrounding soil collapsing into the annulus gap, cement grout was injected into this
Fig. 4. Ground conditions penetrated by piles $13 / 4$ and $10 / 5$.

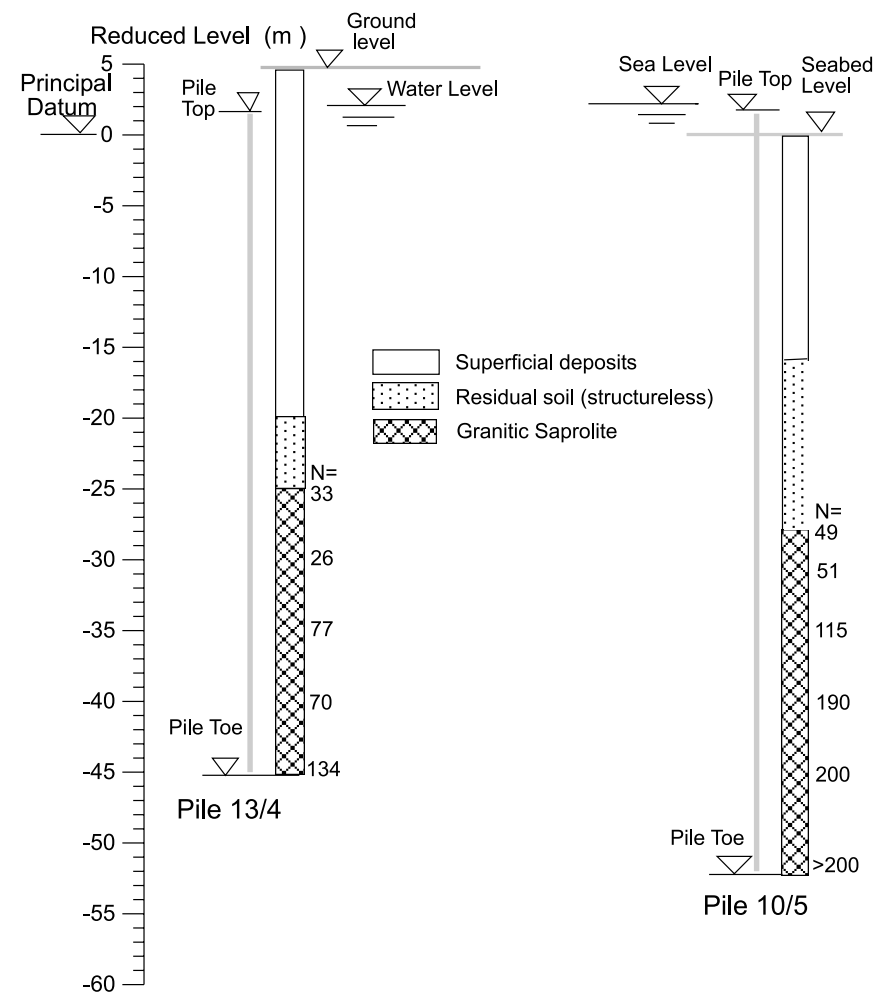

Fig. 5. Ground conditions penetrated by pile $72 / 2$.

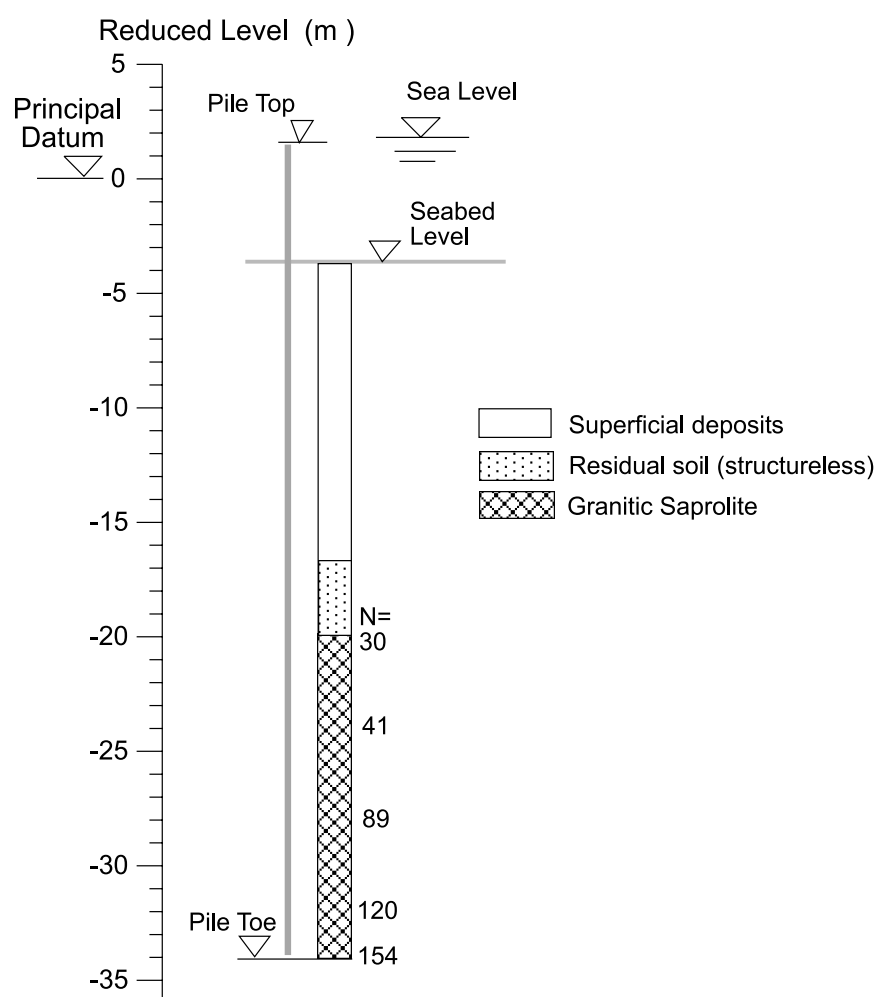

Pile $72 / 2$ 
Fig. 6. Ground conditions penetrated by piles $6 / 4$ and $17 / 4$.

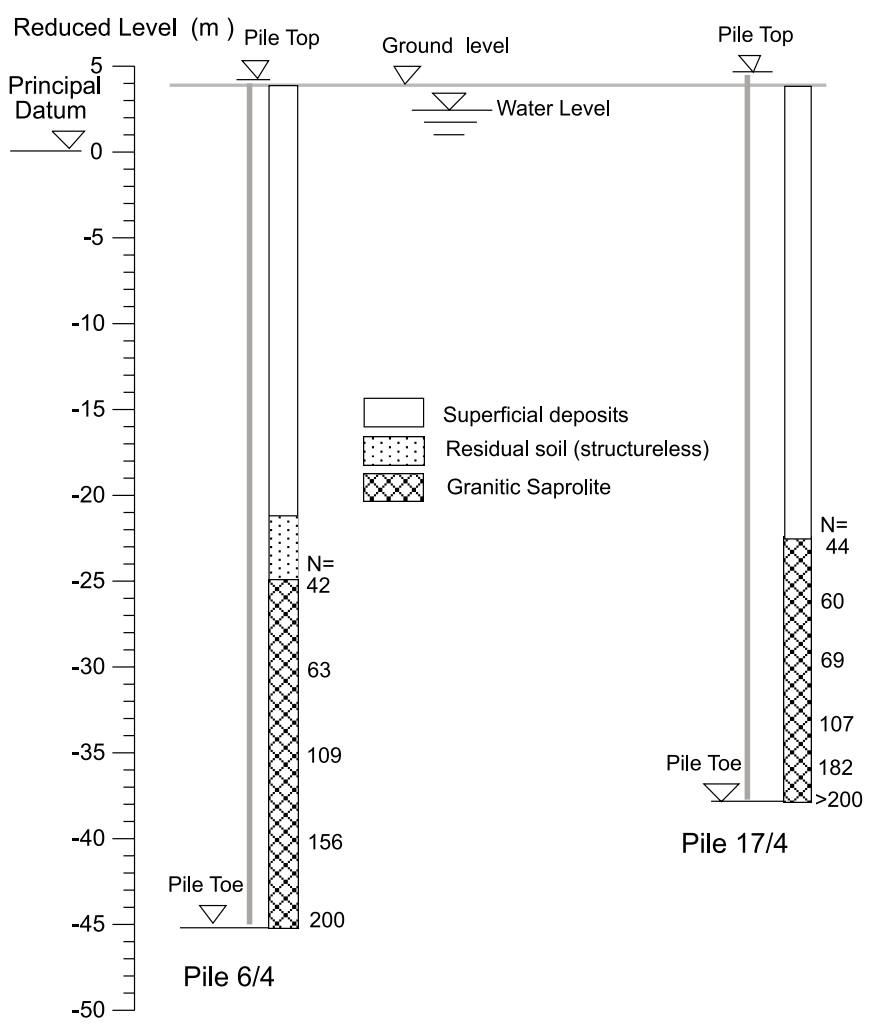

material after withdrawal of the excavation casing. The load-settlement curve of this test pile is presented in Fig. $7 a$. Evidently the grouting of the collapse-in loose soils was not completely successful and the load test was terminated prior to the application of full test load. The ultimate skin friction registered by the strain gauges (Fig. $7 b$ ) was $\sim 27 \mathrm{kPa}$ for the depths 36.5-44 m, despite the grouting of the loose soil in the annulus. The corresponding $\tau_{\mathrm{f}} / N$ value was very low at 0.196 . A reasonable, although still low value of $\tau_{\mathrm{f}} \approx 70 \mathrm{kPa}$ was achieved for the depths $28.5-36.5 \mathrm{~m}$, indicating that the grouting was more effective along this pile segment. The base stiffness of this pile, however, was high and among the group of highest base stiffness values of all 22 piles in the data base. A second test pile 17/4 was constructed on the same site by the same contractor using the same equipment, but without the use of a liner (and no grouting) in the saprolite stratum. The second test pile manifested superior load-settlement performance compared with the first test pile (Fig. 7a). The skin friction mobilized at maximum test load was $130 \mathrm{kPa}$ (Fig. 7b). Since these two tests piles were constructed by the same construction crew using the same equipment in similar ground conditions, the adverse effect of using a full-length permanent liner was convincingly demonstrated.

\subsection{Theoretical assessment and back-analysis of skin friction}

The skin friction, $\tau_{f}$, is governed by the following failure equation expressed in effective stress:

$$
\tau_{\mathrm{f}}=\sigma_{\mathrm{r}}^{\prime} \tan \delta+c_{\mathrm{a}}^{\prime}
$$

where $\sigma_{\mathrm{r}}^{\prime}$ is the effective radial stress acting on the pile-soil interface after pile installation, $\delta$ is the interface friction angle, and $c_{\mathrm{a}}^{\prime}$ is the interface adhesion. As a consequence of the pile excavation, any contribution from $c_{\mathrm{a}}^{\prime}$ is considered negligible and eq. [2] can be simplified to the following:

$$
\tau_{\mathrm{f}}=\sigma_{\mathrm{r}}^{\prime} \tan \delta
$$

A corrugated liner ensures a rough interface, and hence $\delta=\phi$, the effective friction angle of soil. Since the soil collapse in the annulus void is in a loose state, $\phi$ approaches $\phi_{c v}$, where the subscript $\mathrm{cv}$ denotes the critical void ratio state. Therefore, $\delta \approx \phi_{\mathrm{cv}}$, and this leads to

$$
\tau_{\mathrm{f}}=\sigma_{\mathrm{r}}^{\prime} \tan \phi_{\mathrm{cv}}
$$

It is sometimes assumed that the annulus of loose soil is close to an at-rest state. For $\phi_{\mathrm{cv}}$ in the range of $32-38^{\circ}$ and assuming $K_{0}=1-\sin \phi_{\mathrm{cv}}$, where $K_{0}$ is the at-rest earth pressure coefficient, $\beta \approx 0.3$. This value is considerably higher than the back-analysed $\beta$ values of the four piles constructed with full-length liners. Hence such a simplified analysis cannot predict the low skin friction value.

\section{Numerical modelling of the effects of a liner}

In an attempt to understand how the incorporation of a permanent liner can reduce the skin friction to a very low value, the genesis of the annulus of loose material was numerically simulated. A $12 \mathrm{~m}$ representative pile length in saprolites overlain by thick superficial deposits was modelled by an axisymmetric idealization as illustrated in Fig. 8. The diameter of the pile was $2 \mathrm{~m}$, and the initial width of the annulus gap was taken as $150 \mathrm{~mm}$. The superficial deposits were modelled by the application of an equivalent pressure of $198 \mathrm{kPa}$, which corresponded to $\sim 25 \mathrm{~m}$ of overburden. This simplification is tenable because $\tau_{\mathrm{f}}$ and $\sigma_{\mathrm{r}}^{\prime}$ of the saprolite stratum were the main concern. The concrete pile was modelled as elastic elements, and with interface elements along the periphery of the pile shaft. These interface elements can track "opening and closing" of a gap. A MohrCoulomb elastic-plastic model was used for the soil. The parameters for the virgin saprolite were taken as $\phi=39^{\circ}$, cohesion intercept $c=20 \mathrm{kPa}$, Young's modulus $E=30 \mathrm{MPa}$, and Poisson's ratio $\mu=0.3$. It is important to reemphasize that the cohesion value can be the result of linearizing a curved failure surface and does not imply the presence of true bonding.

The analysis is a multistage, incremental, large-deformation analysis using a finite difference stress analysis program FLAC (Itasca Consulting Group Inc. 1998). The initial horizontal to vertical effective stress ratio was taken as 0.38 . The collapsing of soil into the gap can be modelled by either a "fill-in" mechanism or a "close-in" mechanism (Fig. 9). In the fill-in mechanism, the pile bore excavation in the saprolite stratum is assumed to remain stable temporarily, even after casing withdrawal, say due to a partially drained state; but the weaker overlying deposits collapse and fill in the gap (Fig. 9a). The saprolite will eventually reach a drained state and exert lateral stress on the in-fill material. The "close-in" mechanism assumes that the surrounding soil cannot main- 
Fig. 7. Comparison of pile performance: (a) load-displacement curves; $(b)$ mobilization of side friction.

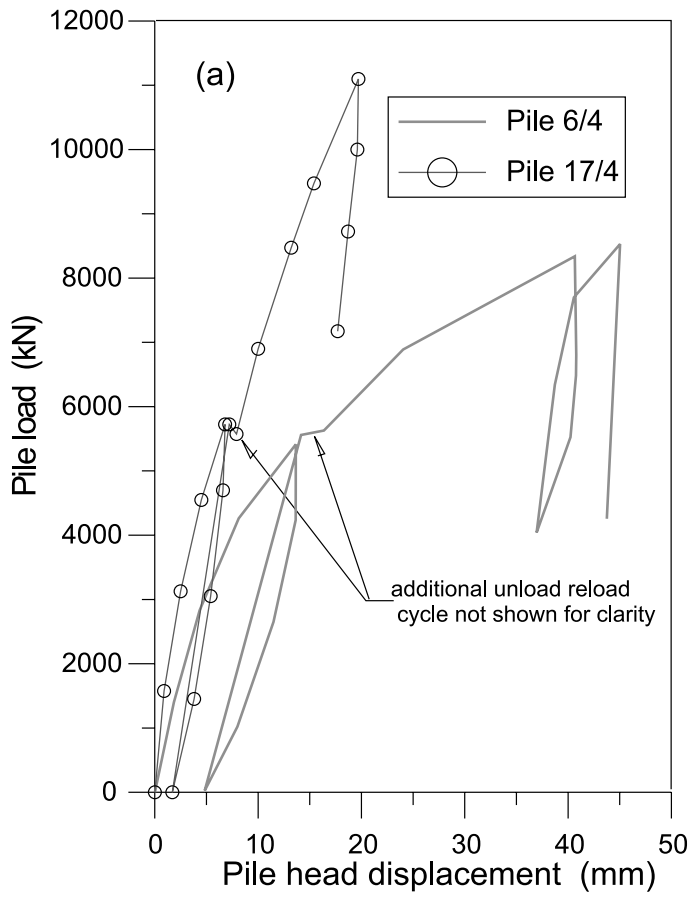

Fig. 8. Configuration for analysing the effects of a permanent liner.

axes of symmetry

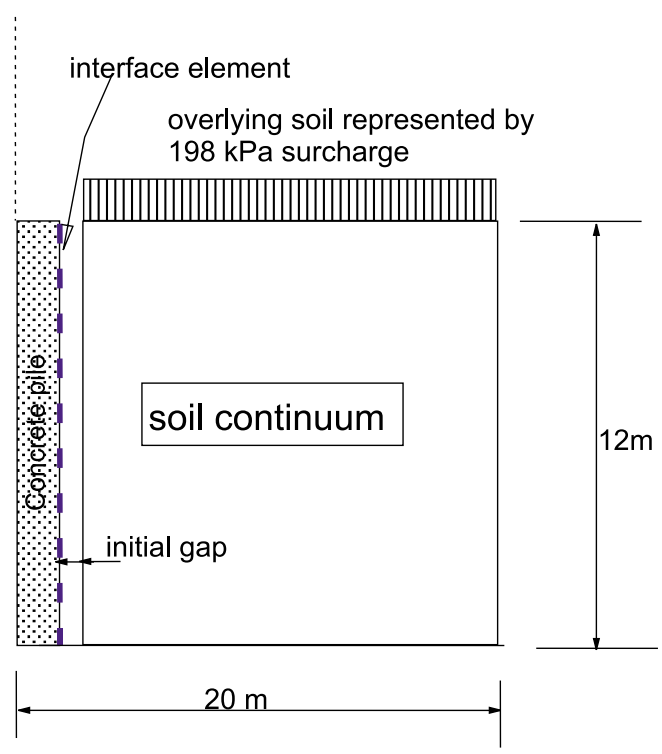

tain any significant pore-water suction during casing withdrawal, and therefore will close in towards the pile during withdrawal of the excavation casing (Fig. 9b). These two mechanisms can be modelled by coding user-defined macros in FLAC. The modelling details are presented in Appendix B. In reality, both fill-in and close-in mechanisms would occur simultaneously, although one mechanism may dominate. The modelling, although complicated, is considered only approximate.

The distributions of effective radial stress next to the pile

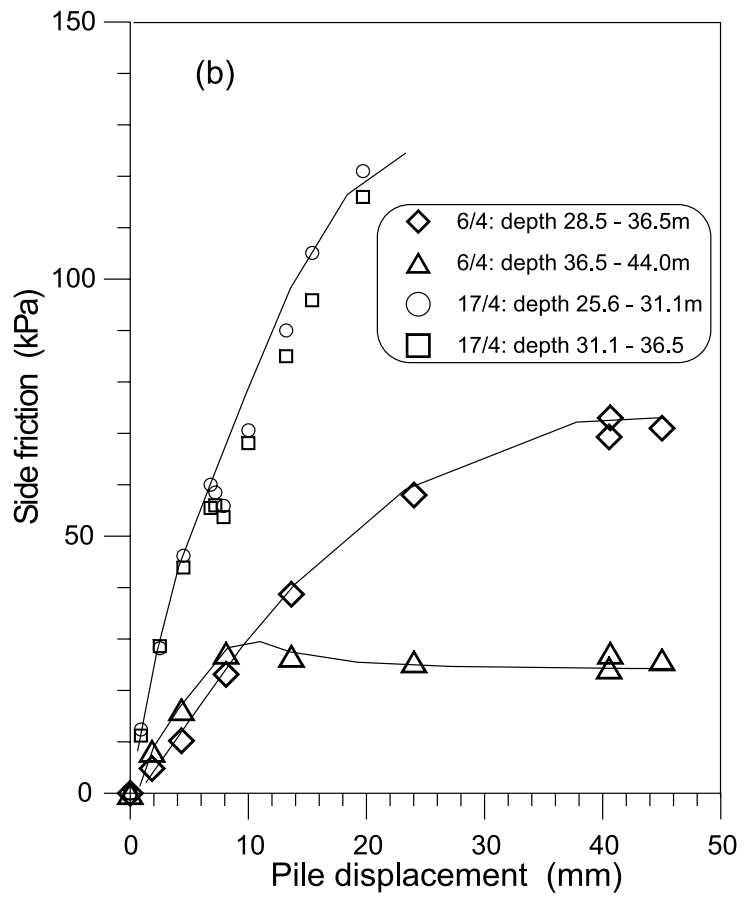

Fig. 9. Collapse mechanisms: (a) fill-in mechanism; (b) close-in mechanism. (a)

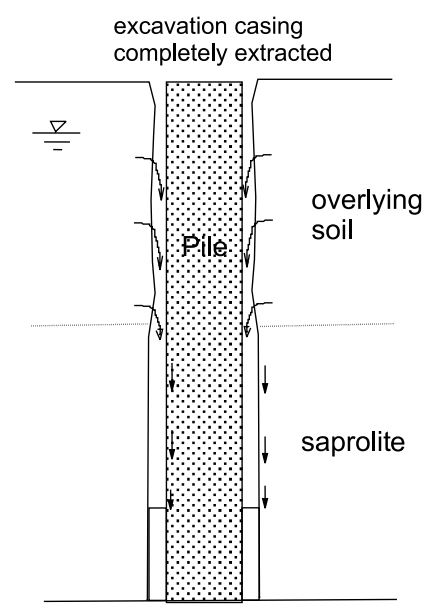

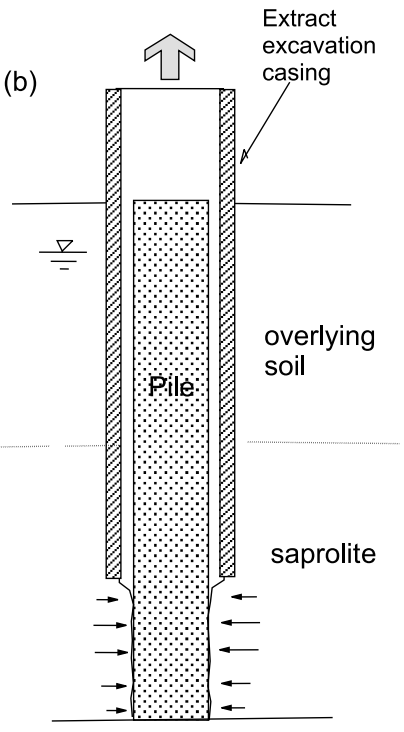

shaft, $\sigma_{\mathrm{r}}^{\prime}$, were plotted in Fig. 10 for both mechanisms. The initial effective horizontal stress (as given by 0.38 times the initial effective vertical stress) was also plotted in Fig. 10 for comparison. The value of $\sigma_{r}^{\prime}$ calculated based on a fill-in mechanism (as indicated by open circles in Fig. 10) was approximately constant with depth and had an average value of about $20 \mathrm{kPa}$, which was considerably lower than the initial effective horizontal stress. Hence, the average skin friction predicted by eq. [4] based on a high estimate of $\phi_{\mathrm{cv}}=38^{\circ}$ was $15.6 \mathrm{kPa}$. The $\sigma_{\mathrm{r}}^{\prime}$ calculated based on a close-in mechanism was close to the initial effective horizontal stress at the top of the pile segment but rapidly reduced to values considerably lower than the initial effective horizontal stress at 
Fig. 10. Effective radial stress next to pile shaft.

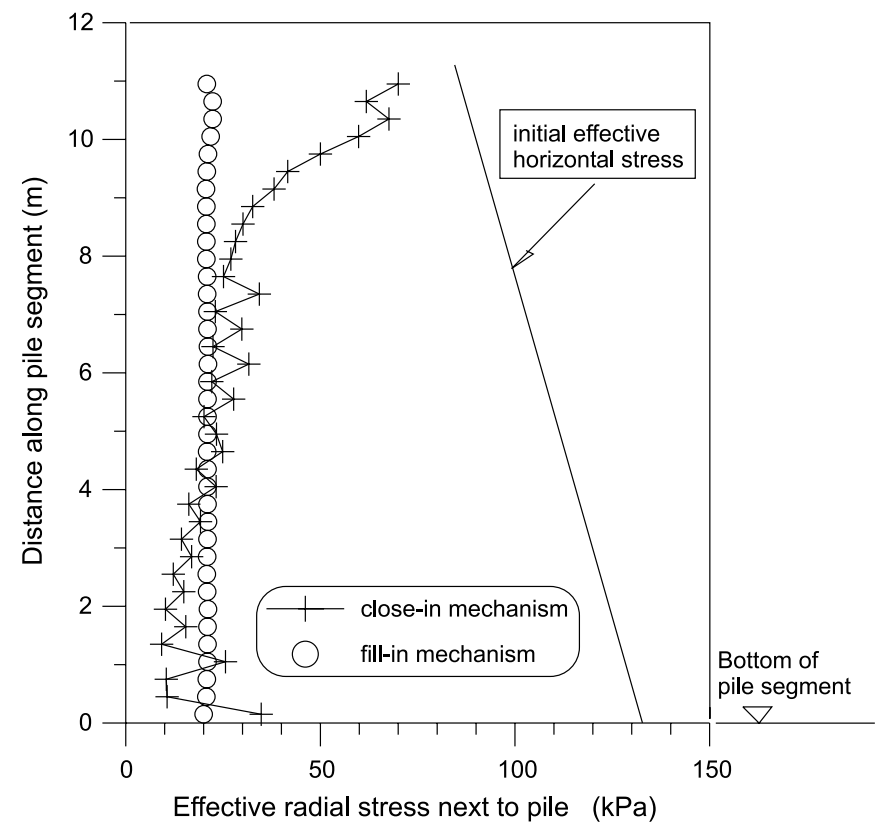

greater depths. The average $\sigma_{\mathrm{r}}^{\prime}$ value was about $29.5 \mathrm{kPa}$. Hence, the average skin friction predicted by eq. [4] based on a high estimate of $\phi_{\mathrm{cv}}=38^{\circ}$ was $23 \mathrm{kPa}$. Therefore, both mechanisms give very low skin friction values that are consistent with load test results as discussed in Sect. 4.2. The variation of $\sigma_{\mathrm{r}}^{\prime}$ with radial distance (at mid-depth of the pile segment) was plotted in Fig. 11. For both collapse mechanisms, $\sigma_{\mathrm{r}}^{\prime}$ increased back to the initial effective horizontal stress at about $6 \mathrm{~m}$ from the pile shaft.

The distribution of effective circumferential stress, $\sigma_{\theta}^{\prime}$, with radial distance is presented in Fig. 12 for both mechanisms. Although the distribution of $\sigma_{\theta}^{\prime}$ is dependent on the assumed mechanism, a general trend can be identified for both mechanisms. The value of $\sigma_{\theta}^{\prime}$ increased from a very low value near the pile-soil interface to a "peak" at about 1-3 m from the pile-soil interface, depending on the assumed mechanism. The peak value of $\sigma_{\theta}^{\prime}$ is significantly higher than the initial effective horizontal stress. With increasing distance from the pile, $\sigma_{\theta}^{\prime}$ then reduced from the peak value to the initial effective horizontal stress. This is indicative of horizontal stress arching as illustrated in Fig. 13. The horizontal soil arch resists the far-field effective radial stress, which is equal to the initial effective horizontal stress, so the effective radial stress in the vicinity of the pile shaft is at a low value.

Over 20 variations of the aforementioned analysis were conducted, reflecting different assumptions, different penetrations into the saprolite stratum, and different thicknesses of superficial deposits. Although the quantitative results depended on the assumptions made, the qualitative finding that $\sigma_{\mathrm{r}}^{\prime}$, and hence skin friction, was always very low and that the presence of stress arching remained valid. This provides a consistent explanation for the observed low skin friction for large-diameter bored piles constructed with a full-length permanent liner.
Fig. 11. Variation of effective radial stress with distance from pile.

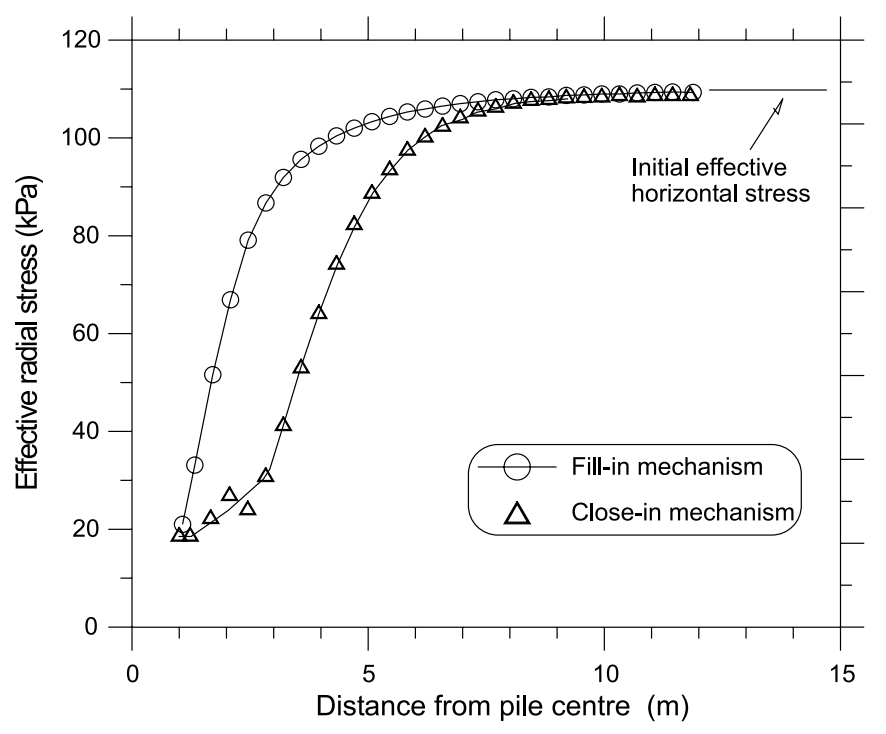

Fig. 12. Variation of effective circumferential stress with distance from pile.

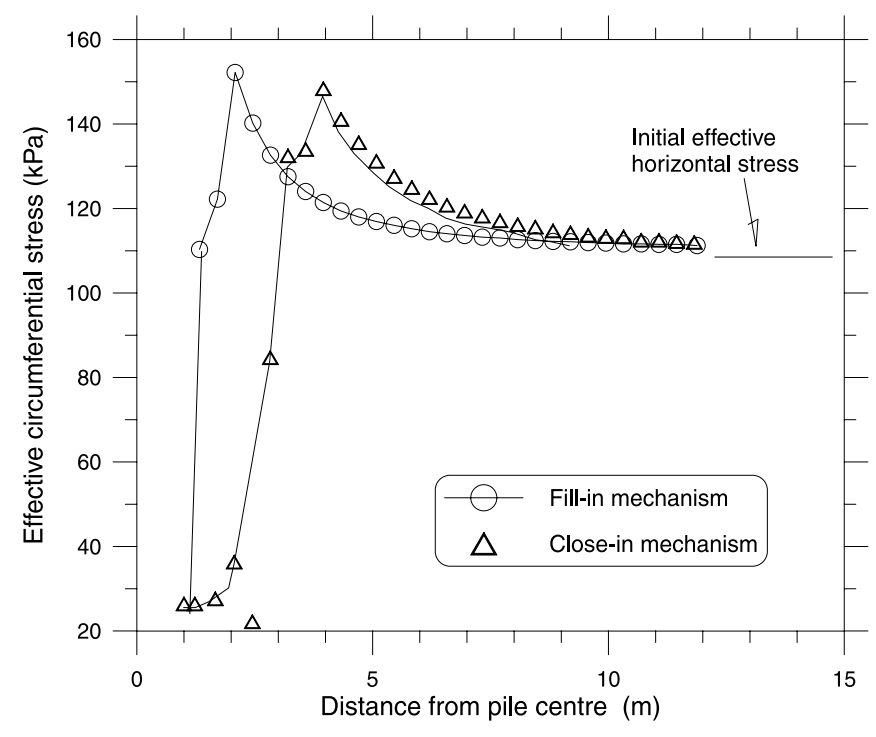

\section{Discussion and conclusions}

A study of maintained load test results of 22 largediameter bored piles founded in Hong Kong granitic saprolites showed highly variable skin friction values. Bored piles constructed with a full-length (corrugated) permanent liner, however, always manifested extremely low skin friction.

A series of numerical analyses with detailed simulation of pile installation were conducted to evaluate the stress configuration in the vicinity of a bored pile installed with a full-length permanent liner. The results of the numerical simulation unambiguously indicate that the effective radial stress in the vicinity of the pile shaft will be reduced to an extremely low value (compared with the initial effective horizontal stress) as a result of the pile installation procedure using a full-length permanent liner. This is because a soil 
Fig. 13. Horizontal stress arching.

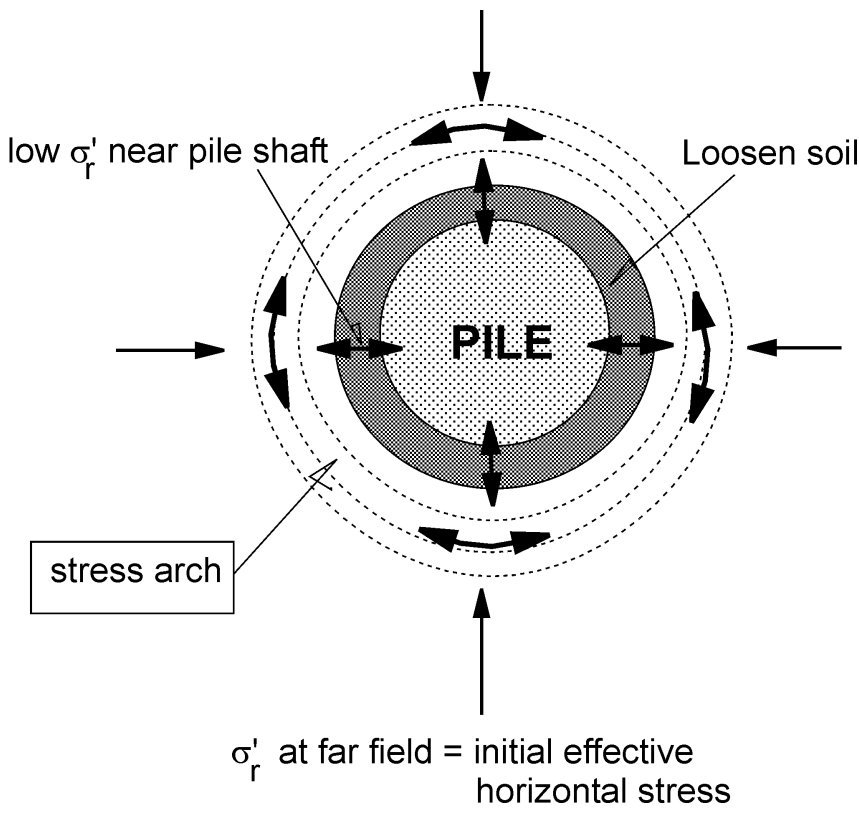

arch was formed to resist the far-field effective radial stress, which is equal to the initial effective horizontal stress, thus leading to low effective radial stress in the vicinity of the pile shaft.

The extremely low effective radial stress in the vicinity of the pile shaft will give very low skin friction values, even if a high pile-soil interface friction angle was assumed.

This implies that large-diameter bored piles relying on side friction should not be installed with a full-length permanent liner in saprolites unless special techniques to reintroduce the effective radial stress along the pile-soil interface are implemented.

\section{Acknowledgements}

The work described in this paper was partly supported by a grant from the Research Grants Council of the Hong Kong Special Administrative Region, China (Project HKU 7006/ 01E). Part of the data analysis reported in this paper was conducted while the first author was on special studies leave at the Hong Kong University of Science and Technology. The assistance from many friends in industry are gratefully acknowledged.

\section{References}

Au, S.W.C. 1990. Some observations on horizontal drain flow and piezometric response. In Proceedings of the 6th International Congress of the Association of Engineering Geology, Amsterdam, 610 Aug. 1990. Vol. 2. Edited by D.G. Price. A.A. Balkema, Rotterdam, The Netherlands. pp. 1149-1156.

$\mathrm{Au}$, S.W.C. 1998. Rain induced slope instability in Hong Kong. International Journal of Engineering Geology, 5: 1-36.

$\mathrm{Au}$, S.W.C., and Lo, S.-C.R. 1993. Use of waterhead support in the construction of large diameter bored piles: potential savings and problems. In Proceedings of the 11th Southeast Asian Geotechnical Conference, Singapore, 5-9 Sept. 1993. pp. 489494.
Chang, M.F., and Broms, B.B. 1991. Design of bored piles in residual soils based on field-performance data. Canadian Geotechnical Journal, 28(2): 200-209.

Chang, M.F., and Wong, J.H. 1995. Axial load test behaviour of bored piles in weathered granite. In Proceedings of the 10th Asian Regional Conference in Soil Mechanics and Foundation Engineering, Beijing. Vol. 1. pp. 185-188.

Fraser, R.A. 1985. Design of bored piles. Hong Kong Engineer, January 1985 , pp. 37-48.

Fraser, R.A., and Kwok, D. 1986. Mobilization of skin friction in bored piles in Hong Kong. In Proceedings of the International Conference on Deep Foundations, Beijing. Vol. 2. pp. 2.652.74 .

GEO. 1993. Guide to retaining wall design. Geotechnical Engineering Office, Hong Kong Government, Hong Kong.

GEO. 1996. Pile design and construction. GEO Publication 1/96, Geotechnical Engineering Office, Hong Kong Government, Hong Kong.

Holt, D.N., Lumb, P., and Wong, P.K.K. 1982. Site control and testing of bored piles at Telford Gardens, an elevated township at Kowloon Bay, Hong Kong. In Proceedings of the 7th Southeast Asian Geotechnical Conference, Hong Kong, Nov. 1982. pp. 349-361.

Hong Kong Government. 1995. Pile foundations. Practice Note for Authorized Person and Registered Structural Engineer PNAP141, Buildings Department, Hong Kong Government, Hong Kong.

Irfan, T.Y. 1996. Mineralogy fabric and classification of weathered granites in Hong Kong. Quarterly Journal of Engineering Geology, 29: 5-35.

Itasca Consulting Group Inc. 1998. Fast Lagrangian analysis of continua (FLAC), version 3.4, user guide. Itasca Consulting Group Inc., Minneapolis, Minn.

Kay, J.N., and Kalinowski, M. 1997. Shaft friction for cast-in place piles in Hong Kong. In Proceedings of the International Symposium on Structures and Foundations in Civil Engineering, Hong Kong, 7-10 Jan. 1997. Hong Kong University of Science and Technology, Hong Kong. pp. 1-6.

Kwok, D. 1987. Construction of large diameter bored piles founded on soil. M.Sc. thesis, The University of Hong Kong, Hong Kong.

Leroueil, S., and Vaughan, P.R. 1990. The general and congruent effects of structures in natural soils and weak rocks. Géotechnique, 40(3): 467-488.

Lo, S-C.R., and Li, K.S. 1999. Challenges in the design and construction of large diameter bored piles founded in decomposed granite. In Proceedings of the Conference on Construction Challenges into the Next Century. 2-3 Dec. 1999, University of Hong Kong, Hong Kong. pp. 84-91.

Lo, S-C.R., and Li, K.S. 2000. Large diameter bored piles founded in Hong Kong decomposed granite. In Proceedings of the International Conference on Geotechnical and Geological Engineering, GeoEng2000, Melbourne, 19-24 Nov. 2000.

Lumb, P. 1962a. The properties of decomposed granite. Géotechnique, 12(3): 226-243.

Lumb, P. 1962b. General nature of soils of Hong Kong. In Proceedings of the Symposium on Hong Kong Soils, Hong Kong, 22 and 29 May 1962. pp. 19-32.

Lumb, P. 1965. The residual soils of Hong Kong. Géotechnique, 15(2): 180-194.

Lumb, P. 1975. Slope failures in Hong Kong. Quarterly Journal of Engineering Geology, 8: 31-65.

Lumb, P. 1983. Engineering properties of fresh and decomposed granites from Hong Kong. Quarterly Journal of Engineering Geology, 19: 81-94. 
Malone, A.W., Ho, K.K.S., and Lam, T.S.K. 1992. Piling in tropically weathered granite. In GEOTROPIKA'92, Proceedings of the International Conference in Geotechnical Engineering, 2123 April 1992, Universiti Technologi Malaysia, Kuala Lumper, Malaysia.

Meyerhof, C.G. 1976. Bearing capacity and settlement of pile foundations. Journal of the Geotechnical Engineering Division, ASCE, 102(3): 196-228.

Ng, C.W.W., Rigby, D.B., Li, J.H.M., Yau, T.L.Y., Lee, S.C., and Carlton, C. 2000. Shaft resistance of large diameter bored piles constructed under water in saprolites. In Proceedings of the 19th Annual Seminar of the Geotechnical Division, Hong Kong Institution of Engineers, Hong Kong, 12 May 2000. pp. 135-144.

Poulos, H.G., and Davies, E.H. 1980. Pile foundation analysis and design. Wiley and Sons, New York.

Reese, L.C., and O’Neill, M.W. 1988. Drilled shaft: construction procedures and design method. U.S. Department of Transportation, Federal Highway Administration, FHWA Publication FHWA-HI-88-042.

Reese, L.C., and Wright, S.J. 1977. Design shaft manual: construction procedures and deign for axial loading. Vol. 1. U.S. Department of Transportation, Implementation Division, HDV-22, Implementation Package 77-21.

Ruxton, B.P., and Berry, L. 1957. Weathering of granite and associated erosion features in Hong Kong. Bulletin of the Geological Society of America, 68: 1263-1291.

Silva, S.D., Cheung, C.T., Pratt, M., and Walsh, N. 1998. Instrumented bored and barrette pile load test for western harbour crossing. In Proceedings of the 17th Annual Seminar, Geotechnical Division, Hong Kong Institution of Engineers, Hong Kong, 29 May 1998. pp. 77-94.

Tan, Y.C., Chen, C.S., and Liew, S.S. 1998. Load transfer behaviour of cast-in place bored piles in tropical soils of Malaysia. In Proceedings of the 13th Southeast Asian Geotechnical Conference, 16-20 Nov. 1998, Taipei, Taiwan. pp. 563-571.

Touma, F.T., and Reese, L.C. 1974. Behaviour of bored piles in sand. Journal of the Geotechnical Engineering Division, ASCE, 100(7): 749-761.

\section{Appendix A: Analysis of load test data}

Maintained load tests were conducted on a number of fullscale large-diameter bored piles in Hong Kong. The maximum test load is generally 1.5 to 2 times the allowable (working) load. Key test data for test piles instrumented with strain gauges for measurement of skin friction are summarized in Table 1. In tests where skin friction was not fully mobilized at the maximum test load, an extrapolated value based on a displacement of $1 \%$ of the pile diameter was assigned. Table 2 summarizes other load test results where skin friction was not directly measured with strain gauges, but some inferences could be made from the load-settlement responses based on Poulos and Davis (1980). The test data in Tables 1 and 2 are from GEO (1996), publications in the public domain, and the author's knowledge and (or) involvement with projects. The construction method is described in two columns in the tables, Excavation method and Concreting details. Additional descriptors for the excavation method (such as HG+ and HG\#) are used when appropriate.

In view of the large variability as evident from Table 3, the possibility of correlation between $N$ and the $\tau_{\mathrm{f}} / N$ ratio was examined. No clear correlation can be identified.
Furthermore, one cannot make any general statement on whether HG or RCD will give higher skin friction.

The load test results were compared with common design correlations for bored piles in sandy soil. Meyerhof (1976) suggested that a conservative estimation of skin friction for bored piles is given by the following:

\section{[A1] $\tau_{\mathrm{f}} / N=1$}

The $\tau_{\mathrm{f}} / N$ ratio of unity is close to the mean value as listed in Table 3B for granitic saprolite, but the mean value in Table $3 \mathrm{~B}$ is very different from a conservative estimate because of the very high variability (coefficient of variation $\mathrm{COV}=$ $48 \%$ ).

It is recognised that the data presented by Meyerhof (1976) are mainly for $N \leq 60$, whereas the $N$ values for saprolite are, in general, considerably higher. Therefore a second comparison was made with the empirical design correlation as proposed by Reese and Wright (1977) for $N$ in the range of 53-100 and reproduced in $\mathrm{kPa}$ units as follows:

$$
\tau_{\mathrm{f}}=160+100\left(\frac{N-53}{450}\right)
$$

This equation gives $\tau_{\mathrm{f}} / N$ of 2.7 at $N=60$, and the ratio reduces to 1.2 at $N=150$. Therefore eq. [A2], a design equation that is supposedly conservative, also overestimates the $\tau_{\mathrm{f}} / N$ ratio by a significant extent.

Touma and Reese (1974) recommended a $\beta$ value in the range of $0.5-0.7$, which is significantly higher than the mean value in Table $3 \mathrm{~B}$.

Reese and O'Neill (1988) suggested that $\beta$ should be correlated to pile penetration but has a lower bound value of 0.25 . This lower bound value is close to the mean $\beta$ value as listed in Table 3B. In view of the large variability in $\beta$ $(\mathrm{COV}=53 \%)$, however, it cannot be considered as a conservative design value.

Although the aforementioned design correlations do not give conservative predictions relative to the measured values, most of the test piles achieved high friction capacity (provided piles constructed with full-length permanent liners were excluded). This is because of ( $i)$ the high $N$ values in granitic saprolite and the depth where the saprolite stratum was located, therefore giving high $\tau_{\mathrm{f}}$ even if the $\tau_{\mathrm{f}} / N$ ratio or $\beta$ are significantly lower than those given by common design correlations; and (ii) the large pile diameter and the long pile penetration of the test pile.

It is pertinent to note that the skin friction values were obtained from large-scale and expensive test piles to verify design and (or) construction procedure(s). It is difficult to justify discounting test results with $\tau_{\mathrm{f}}\left(\right.$ or $\tau_{\mathrm{f}} / N$ or $\beta$ ) values less than the average values. Lo and $\mathrm{Li}(1999,2000)$ pointed out that the influence of pile installation cannot be categorized by simple descriptors such as bore pile, underwater excavation, HG, or RCD. Other factors such as "details" in the sinking of excavation casing, rate of concreting relative to pile diameter and setting time of concrete may also have a significant influence. This means that design based on the mean values as listed in Table 3B needs to be verified by a project-specific load test, which is in line with current practice, unless a very prescriptive construction specification is agreed upon by the piling community of Hong Kong. 


\section{Appendix B: Modelling of collapse into the annulus void}

The analysis is a multistage incremental large deformation analysis using a finite difference stress analysis program FLAC (Itasca Consulting Group Inc. 1998).

The genesis of the fill-in mechanism is simulated by five sets of user-defined procedures for five analysis stages. These five analysis stages, I-V, are explained below.

(I) Installation of casing was modelled by provision of horizontal support (fixity). To model the effect of disturbance due to casing installation, the friction angle was reduced to $\phi_{c v}$ and stiffness parameters were reduced to $60 \%$ of the in situ value in a near-field zone of 0.5 times the pile diameter.

(II) Forming of the concrete piles was modelled by turning appropriate elements into elastic elements. The adjoining column of elements was also turned into null elements (to represent the gap). The interface elements were also activated along the periphery of the concrete pile.

(III) Withdrawal of casing was modelled by progressively removing the lateral support assigned in stage I. The cohesion of the soil, however, was maintained at the in situ value to maintain transient stability of the unsupported soil surface.

(IV) Collapse of soil into the gap was modelled by progressively turning the null elements (representing the gap in stage II) into soil elements with properties of a loose, decomposed granite fill. Soil that collapsed in above the $12 \mathrm{~m}$ segment was represented by the application of an equivalent pressure.

(V) The soil cohesion was reduced to zero in the near-field zone and an intermediate value (between 0 and $20 \mathrm{kPa}$ ) over a transition zone of one times the pile diameter.

This reduction was achieved in 20 increments.

Maintaining $c=20 \mathrm{kPa}$ in the near-field zone during casing withdrawal (stages III and IV) is tenable, as the saprolite may not be likely to achieve a fully drained response during the short period needed to withdraw the casing. The saprolite, being dilatant, will give a transient negative porewater change, which in turn will give a higher transient shear strength. The dimension of the gap allows the overlying (and weaker) soil to collapse into the gap. At stage V, which models the eventual occurrence of a drained response, the surrounding soil imparts additional radial stress.

In modelling the close-in mechanism, only three analysis stages were needed. Stages I and II were the same as those of the fill-in mechanism. Stage III, however, was defined by a different set of procedures. It had two substages, IIIa and IIIb.

(IIIa) The cohesion soil in the vicinity of the pile was assigned the drained soil parameters of zero in the nearfield zone and increasing back to the in situ value in the transition zone prior to casing withdrawal.

(IIIb) Withdrawal of casing was modelled by removing the lateral supports (installed in stage I) progressively on a node-by-node basis, and with the system of equations solved for the removal of each support.

As a result of stage IIIa, the pile excavation will not be self-supporting because of the lack of cohesion. Hence the surrounding soil will "close in" during the progressive removal of support. Closing-in of the soil on the pile surface, and the subsequent generation of radial stress, was tracked by the interface elements activated in stage II. 
Copyright $\odot 2003$ EBSCO Publishing 